\title{
Article
}

\section{Truth versus ignorance in democratic politics: An existentialist perspective on the democratic promise of political freedom}

\author{
Pascal D. König \\ TU Kaiserslautern, 67663 Kaiserslautern, Germany. \\ pascal.koenig@sowi.uni-kl.de
}

\begin{abstract}
Existentialist philosophy offers an understanding of how trying to eliminate ambiguities that inevitably mark the human condition only seemingly leads to freedom. This existentialist outlook can also serve to shed light on how democratic politics may similarly show tendencies which aim at overcoming immanent tensions. Such tendencies in democratic politics can be clarified using Sartre's notion of ignorance - and truth as its counterpart. His concept of ignorance goes beyond merely facts or knowledge and refers to a mode of being. It expresses a subject's desire to avoid, rather than confront, resistances stemming from the world. Based on a distinction of different forms in which this orientation can manifest itself, this article shows how democratic politics, too, can be threatened by ignorance as a way of doing politics. This ignorance comes in different guises which all express a desire to eliminate tensions that democratic politics cannot overcome without undermining itself.

Contemporary Political Theory (2021) 20, 614-635. https://doi.org/10.1057/s41296020-00436-y; advance online publication 25 August 2020
\end{abstract}

Keywords: liberal democracy; existentialism; truth; ignorance; freedom

Ignorance has long been regarded as a threat to democratic regimes. Lippmann (1922) wrote that citizens were too uninformed and their opinions too fickle to guide the decision-making of a democratic government. In a similar vein, Schumpeter (1975, p. 262) warned that citizens receded to a lower level of mental performance when entering the political sphere. While subsequent diagnoses have largely been less harsh and more nuanced, the general problem remains and has not lost relevance. It appears that political sophistication in the populace has been relatively constant over many decades (Somin, 2013). And in a political system that is founded on the rule of the people, citizens' ignorance remains a very serious problem for democracy (Landemore, 2013, p. 37). 
Such diagnoses of ignorance as a lack of political knowledge and competence indeed point to a major threat to the working of democracy. Yet they miss how democratic regimes are also threatened by a different kind of ignorance that can take hold at the heart of politics and which, as the present article argues, existential thought and particularly Jean-Paul Sartre's work can help to clarify. An existentialist outlook refrains from a rationalist quest for completeness and expressly acknowledges the provisional character of all political projects. This makes it valuable for thinking about ambiguities and tensions in democratic politics that can never be entirely overcome. Indeed, such tensions have repeatedly been noted to characterize liberal democracy, understood broadly as a regime that combines a liberal and democratic element and that can take different concrete forms. In particular, the democratic element of giving power to the people and the liberal element of constraining all use of power inevitably and constantly produce frictions within a political system (Canovan, 1999; Mouffe, 2009; Urbinati, 2014).

Drawing on Sartre's (1995) work to examine this enduring source of instability in democratic politics may seem far from a natural connection given existentialism's primary concern with the individual existence and Sartre's criticism of existing liberal-democratic regimes during his time (Busch, 1989; Flynn, 1979; McBride, 2005). However, not only is his thought generally compatible with a postfoundational understanding of liberal democracy, but his notion of ignorance can also enrich this understanding as it allows for formulating a coherent perspective on immanent challenges to democratic politics. Sartre's concept of ignorance is not narrowly cognitivist but instead refers to a mode of being that aims at eliminating frictions and tensions which exist between the self and the world. This notion of ignorance - and truth as its opposite - can be used to shed light on the democratic political process and different shapes that it may take. Specifically, it allows for understanding aspirations to organize democratic politics in ways that promise to overcome its inherent tensions as forms of ignorance.

With this perspective, the present article adds to a body of work from political theory that has engaged with existentialist philosophy. A common core of existing contributions is that existentialism's recognition of the irresolvable contingency and ambiguity in human existence can inform a kind of political engagement and judgment that is sensitive to the plurality and situatedness of lived experiences (Hayden, 2013; Hinchman and Hinchman, 1991; Kruks, 2012; Marso, 2017; Mrovlje, 2019). The existentialist account of ignorance and truth in democratic politics developed below shifts the view from individual political judgment to the level of democratic politics. The resulting perspective on ignorance as an inherent threat to democratic politics points to the direct relevance of existentialist philosophy for democratic theory. It highlights tensions and ambiguities that mark the challenge of steering clear of simplistic solutions for seemingly realizing the rule of the people. 
While this challenge can be seen as part of the fabric of liberal democracy and an always latent threat, it arguably becomes accentuated in contemporary, complex and highly differentiated societies. Their degree of pluralism and contingency easily invites an outright relativist stance or - as the opposite extreme - makes a single higher source of authority appear attractive. And the desire to escape contingency and complexity in these ways likely combines with idealized notions of directly translating citizen preferences into political decisions or isolating decision-making from the volatile passions and opinions of the public for their own good - e.g., by resorting to technocratic or populist solutions.

A tendency to evade rather than confront the messiness of democratic politics in contemporary regimes also becomes palpable in recent diagnoses of a wide-spread disregard for facts, not only in the larger public but also among political actors (Bennett and Livingston, 2018; Nichols, 2017). Amidst rising social tensions and an increasingly fragmented public sphere, it seems there are strong forces that steer democratic politics away from a commitment to facts and truth (Lewandowsky et al., 2017; Suiter, 2016). Sartre's work can speak to these conditions and developments as his writings point to a commitment to truth which is not primarily about staunchly advocating or defending truth or facts against those who would deny them. Rather, Sartre's thought foregrounds that which is prior to convictions or beliefs. It offers an understanding of truth as an orientation that involves an openness and willingness to reveal something new about the world, and thereby also about oneself. A similar orientation also must express itself in the shape of democratic politics if it is to safeguard ongoing pluralist contestation and constantly create unity out of diversity without eliminating the latter.

\section{Truth and ignorance as ways of being}

Existentialist philosophy is generally concerned with the human existence and how the individual comes to terms with the contingency that characterizes the human condition. In this quest, the individual must deal with inevitable ambiguities and tensions in its existence. This fundamental task is a key theme in Sartre's (2012) Being and Nothingness. To characterize the individual who fails to deal with this task, he uses the term bad faith, which is a kind of self-deception and attempt to keep the truth hidden from oneself. Willful but unacknowledged ignorance is therefore at the heart of bad faith, which for Sartre is ultimately a form of selfalienation - and it is to be avoided if the self wants to achieve authenticity and be free.

In Truth and Ignorance (Sartre, 1995), which builds on and complements Being and Nothingness (Sartre, 2012), Sartre uses the related term 'ignorance' instead of bad faith and places less emphasis on the aspect of authenticity. Being explicitly paired with truth as its counterpart, Sartre's notion of ignorance more directly 
expresses an understanding of being as a way of knowing. Sartre's existentialist reading of truth and ignorance altogether offers a concise account of how trying to overcome tensions and resistances by trying to eradicate them only seemingly leads to freedom. Before showing how this account has value for thinking about inherent challenges to democratic politics, it is first necessary to elaborate on Sartre's understanding of truth and ignorance as ways of being in the world.

Ignorance is essentially a state of not wanting to know: A person prefers not to unveil certain aspects of the world and thus the demands with which the world might confront the self. The ignorant subject indulges in the idea that it can remain in a state in which the self does not experience any resistances stemming from the world (Sartre, 1995, p. 52). Sartre has used the example of a husband who has reason to suspect that his wife is cheating on him but does not seize the opportunity to achieve certainty in this matter. Ignorance thus represents a mode of being in which one does not want to uncover that which might be inconvenient or frightening.

Importantly, being in the mode of ignorance is different from not knowing something or being wrong about something. Rather, it is indissolubly linked to wanting. The world discloses to the self, through its resistances, what the self wants and how it relates to the world: "[K]nowledge of what is, is knowledge of what I want' (Sartre, 1995, p. 49). Ignorance, however, means not wanting something to be part of the world because, then, it cannot reveal such resistances. The self prefers to live in the illusion that it does not have to negotiate its relation to the world. As it aims to avoid that one's desires are challenged and possibly altered in response to the world, ignorance for Sartre (1995, p. 50) is the 'project of giving my desire a permanent character of desire'.

In sum, ignorance in the existentialist account represents a way of being and of wanting to be in the world. The same goes for its opposite, truth, which for Sartre is inextricably tied to a practice of unveiling the world. It is strongly informed by Heidegger's account of truth, which deviates from a propositional understanding of truth as correspondence and sees it as an experienced process of disclosure that is always necessarily incomplete, i.e., leaves something concealed (on this see Wrathall, 2011). This process of disclosing is always intentional. Every act of unveiling the world results from a project of the self, an anticipation of the world and the role of the self in it (Sartre, 1995, p. 18). My actions and intentions always carry with them certain assumptions about the world that may be verified - or not.

Truth, like ignorance, is inherently linked to wants and desires. What I unveil about the world results from my anticipations about the world. These anticipations are not some detached, neutral hypothesis. Rather, I am invested in them, I am my own hypothesis, projecting myself into the world (Sartre, 1995, p. 15). What I can reveal about the world depends on the ends I project into it, thereby transcending reality in a specific way (Sartre, 1995, pp. 19-21). These projections are risky. They can clash with the world because my anticipation about reality may turn out 
to be wrong. This outcome, being wrong, is not the opposite of truth, though. It is a precondition and a constant risk of truth as an ongoing process of unveiling. I may be wrong about the world but getting it wrong is an act of unveiling, and one to which I am open while being in the mode of truth (Sartre, 1995, pp. 24-26). In the ongoing process of 'truth in motion' (Sartre, 1995, p. 25; emphasis in original), error is simply a false anticipation that leads to new anticipations.

In contrast to ignorance, truth is characterized by a readiness to unveil the world. It recognizes the possibility of unforeseen experiences and of facing undesirable demands posed by the world. Embracing truth is always an adventure. As Sartre concisely writes: '[T]ruth is experienced or lived ... all truth is lived as danger, effort, risk' (Sartre, 1995, p. 8, emphasis in original). Only where this is the case and where I can go wrong can I experience myself as my own project and does it make sense for Sartre to speak of freedom. Through daring to make anticipations about the world, I choose to be a certain self - instead of some other self - and thereby take responsibility. This ultimately means that there is 'no freedom without truth' (Sartre, 1995, p. 16). Freedom presupposes being ready to accept and to take responsibility for what we draw into being with our projects; it is 'to assume the world as if we had created it' (Sartre, 1995, p. 30, emphasis in original).

Accordingly, truth entails managing one's own desires in a way that is opposed to that of ignorance. It is incompatible with the adamant will that something simply be true. Instead, it entails the ongoing 'perpetual project of adapting itself to the world' (Sartre, 1995, p. 43). This understanding of truth goes beyond a merely epistemic understanding and is mainly about daring to know and to find out - to know oneself, one's desires and how they relate to the world. Rather than being a matter of knowing facts or of intelligence, it is about 'honesty and courage in face of reality' (Cox, 2009, p. 39). A commitment to truth hence entails a general readiness to be in a dialogue with the world, which always includes the possibility to change oneself. Ignorance, as its opposite, wants to avoid the demands that the world and revealed aspects of the world may pose to the self (Sartre, 1995, p. 52). In the extreme, the world of ignorance is the frictionless world of dreams in which desire can remain desire, unchallenged by any revelations about the world (Sartre, 1995, pp. 52-53). It is the projection of having one's desires realized without them being transcended so that they can always remain the anticipation of their fulfillment (Sartre, 1995, p. 51).

Indulging in the delusion that such a state is possible can be a relief. It is ultimately an expression of a fear of being in the world and an escape from the burden of freedom. Sartre has offered various examples of such a stance. However, these examples are presented in an ad hoc fashion, and Sartre has not undertaken an attempt to systematically look at different forms of ignorance. The purpose of the following section is thus to take a more analytical approach that distinguishes and systematizes different forms of ignorance. This account will serve as the basis for 
showing how the existentialist concepts of truth and ignorance can shed light on democratic politics.

\section{Four types of ignorance}

Based on the preceding considerations, embracing truth can be a tedious task. Ignorance, in contrast, is tempting as it is based on the promise to achieve an idealized state in which the self finds itself in perpetual harmony with the world. This promise can take different guises depending on how the relation between the self and the world is organized. One important dimension for distinguishing forms of ignorance can be based on the duality of facticity and transcendence described by Sartre as the source of bad faith (2012, pp. 56-57) - a duality that can be traced back to Heidegger and Kierkegaard. While pure facticity refers to clinging to that which is, pure transcendence is wanting to be entirely free in choosing one's commitments. As relations between the self and the world, they correspond to the difference between yielding to the world and submitting to its demands versus wanting to assimilate the world.

This latter orientation, that of trying to assimilate the world, is an expression of the desire to see oneself mirrored in worldly things or to incorporate these things into the self (Sartre, 1995, pp. 50-51). It is excessive because in its extreme form, it aims toward eradicating the very difference toward the world that can define the self. It is insatiable because it can never be satisfied. An illustrative allegory can be found in the work of David Foster Wallace. The character Norman Bombardini in his novel The Broom of the System (Wallace, 1997) is literally insatiable and obsessively consumes exorbitant amounts of food under the delusion that he will at some point be able to assimilate the entire world.

The opposite tendency amounts to self-abandonment, i.e., surrendering to the demands posed by the world. This orientation corresponds to a different description that Sartre gives of ignorance, which consists in taking 'the point of view of death out of fear of death' (Sartre, 1995, p. 38). It avoids a tension between the self and the world through giving up on one's own volitions. Like the desire to assimilate the world, the submissive orientation equally undermines a dialogical relationship with the world in which the self is ready to adapt its wants and desires.

Trying to assimilate the world to the self or the self to the world can each furthermore occur in two variants. This second distinction is implicit to Sartre's (1995) as well as Fromm's (1994) descriptions of subjects trying to escape freedom. ${ }^{1}$ These attempts can either be endowed with a clear direction or they may lack any such direction. In the first case, the individual clings to a specific worldview or belief to which the self has to adhere in order to be in a state of harmony with the world. In the second case, the self does not cling to any such guiding vision. Both these orientations are equally incompatible with the 
existentialist notion of truth because they imply a lack of readiness to engage with the world and renegotiate one's beliefs and desires.

Combining the first distinction - assimilation of the world versus assimilation of the self to the world - with the second one - monism versus relativism - leads to altogether four existential orientations that represent different ways of being in the mode of ignorance. These are summarized in Table 1 and will be described in the following.

Turning first to the right-hand column of Table 1, one finds two existential orientations that aim at assimilating the world to the self and thus bringing it under control - with the result that there are no excess demands stemming from the world which the self would have to cope with. This kind of aspiration may, in a first variant, mean obsessively clinging to a certain vision of the self and the world. In that case, it amounts to fundamentalism or dogmatism: the self insists on aligning the world with a specific worldview or identity while not recognizing any other views. It amounts to ignorance because it means indulging in the belief that the self can perfectly stay true to itself and its worldview. One can observe this kind of orientation realized, for instance, in strong ethnic, political, or religious identities. They all dismiss the idea that change is inevitable and that there is no such thing as a pure identity - since every identity is always necessarily defined and contaminated by what is external to it (Taylor, 1989).

In a second variant, the desire to assimilate the world does not follow a clear direction and is instead marked by a lack of committed to any worldview or identity. Rather, the self develops and is guided by variable wants and desires, and whatever desire it experiences at a given point is to be immediately satisfied. It seeks gratification of a kind that does not foresee a dialogical relationship with the world. This orientation corresponds closely to what Sartre (1995, p. 51) describes as 'the freedom that enjoys to the detriment of the freedom that does'. It suspends the reality principle and wants to remain in the state of wishing (Sartre, 1995, p. 71). In this existential stance, the self wants to be able to follow every desire and urge that it has. It thus amounts to a sort of solipsist and narcissist orientation that follows a hedonistic impulse of perpetual stimulation, of always getting what one wants in and endless succession of gratifying experiences. This orientation too is insatiable, and it amounts to ignorance because it does not make room for a reflexive stance toward one's desires. ${ }^{2}$

Running counter to the two modes of ignorance described so far are two existential orientations that equally aim to eradicate any tensions between the self and the world. Yet they do so by subordinating the self to demands stemming from the world: Through relinquishing its wants and desires, the self finds itself in a world that does not pose excessive demands. Up to some point, this can serve the purpose of arranging oneself with the world by accepting and taking responsibility for it, as Sartre (1995, p. 46) writes. He takes the example of a person having lost an arm in an accident and accepting this changed reality instead of clinging to the old 
Table 1: Four ways of being in the mode of ignorance.

\begin{tabular}{lll}
\hline & $\begin{array}{l}\text { Self-abandonment: assimilating } \\
\text { the self to the world }\end{array}$ & $\begin{array}{l}\text { World appropriation: } \\
\text { assimilating the world to the self }\end{array}$ \\
\hline $\begin{array}{c}\text { Adhering to a single guiding } \\
\text { vision of the self/world }\end{array}$ & Conformism & Fundamentalism/dogmatism \\
$\begin{array}{c}\text { Not adhering to any guiding } \\
\text { vision of the self/world }\end{array}$ & Fatalism & Solipsism \\
\hline
\end{tabular}

self. While this means adapting to the world, it is not a submission to the world without renegotiating one's wants in dialogue with the world. Blind submission, in contrast, is a case of ignorance and can again take two forms.

In the first variant, the self gives up on asserting its own desires against the world and instead submits to and completely identifies with specific demands that stem from the world. It thus conforms to a specific vision of the world as it is expressed in beliefs, ideas or identities. Such a conformism can be tempting as the self can derive value - including self-worth and recognition - from a higher authority to which it submits itself. For instance, the charismatic authority described by Weber (1978, pp. 241-269) is based on an emotional attachment to a charismatic leader rooted in a belief in the exceptional, possibly divine traits and abilities of this person. Her or his followers may even perceive this leader as chosen by destiny. Believing in this special status justifies complete identification with this leader and her or his goals and actions. Succumbing to the authority of a charismatic leader means clinging to the hope that this leader will take care of societal problems such that the world, again, does not pose excessive demands to the self. Similarly, the submission under religious beliefs and authority can serve to free the self from the burden of arranging its relation to the world and finding out what it should want (Fromm, 1994).

Tendencies of conformism have also been extensively studied in socialpsychological research, which has repeatedly shown that individuals particularly emphasize relevant group identities when confronted with insecurities, fears and anxieties because social identities offer a source of self-esteem as well as feelings of security and orientation (e.g., Fritsche et al., 2011). Conformism can thus also take the form of complete subordination under an identity or worldview of a certain social group. In any case, it amounts to ignorance to the degree that it adheres to the belief that a tension between the self and the demands of the world can permanently be eliminated.

Finally, if the assimilation of the self to the world lacks a firm point of reference, if any kind of demand from the world is simply taken as given, ignorance takes the form of fatalism. Whichever demands the world poses to the self, it puts up with 
and succumbs to them. The self has no clear compass as it lacks a solid understanding of itself. Consequently, possible decisions and their outcomes cannot be brought into a stable relation to the self. Similar to conformism, fatalism may be a reaction to excessive demands from the world and a perceived loss of control (Langford, 2002; Mirowsky and Ross, 1990). Resigning to one's fate and to the belief that solutions to the problems in one's life come from external authorities and are an expression of a latent order of things can be comforting and serve to regain a feeling of control.

\section{The political dimension in existentialist truth and ignorance}

The preceding section shows how Sartre's existentialist understanding of ignorance can be used to conceive and systematize worldly orientations of a subject shying away from being in dialogue with the world. Such an impulse to escape the burden of freedom has also been described in the psychoanalytic work of Fromm (1994) a theme that has been revitalized in the writings by Strenger (2005). And even Sartre himself has provided a psychoanalytic reading of the kind of self-deception involved in ignorance (Sartre, 2012, pp. 565-568, 580-581). However, while the four kinds of ignorance described above all refer to ways in which a subject regulates desire in face of experienced resistances, they should not be overly psychologized. Rather than being tendencies that are located merely in the individual they noticeably evince a relation to the broader social context.

Indeed, the kind of willful self-deception involved in ignorance, for Sartre, is tightly linked to the relation between self and other. In Being and Nothingness, the other is encountered as a being that objectifies the self and therefore appears as a threatening experience - and the self is prone to respond with an objectifying stance (Sartre, 2012, pp. 259-260, 526). A propensity to cling to either pure facticity or transcendence therefore often stems from relations to the other (Kail, 2009, p. 145; Webber, 2007, pp. 120-123): In encountering others, the self may want to completely objectify them, ascribing them fixed traits (transcendence), or enjoy being objectified itself (facticity).

As Webber (2007, pp. 119-120) notes, this pessimistic account of social relations is not an inevitable state of human affairs. Rather, the described antagonistic relationship between self and other emerges as a result of being in the mode of ignorance (or bad faith in Being and Nothingness). Avoiding such ignorance means being open to the other and not ascribing this other a fixed identity based on preconceived ideas. Conversely, the self is enabled to be free to the extent that the other averts ignorance. In this sense, the freedom of the self depends on the freedom of the other (Rae, 2014, pp. 86-87; Webber, 2007, pp. 120, 129).

This element of reciprocity is also at the heart of Sartre's understanding of truth. As a general openness toward the world, it also comprises openness to others, i.e., 
not to impose one's truths on them. Revealed truths are to be given (Sartre, 1995, pp. 9-10), they have the character of a gift that others may accept and transcend as they choose. Sartre's notion of truth is therefore bound up with relations to others and is marked by an element of mutuality (see also Mrovlje, 2019, pp. 57, 64). By confronting others in the mode of truth they too are enabled to be committed to truth. If instead a subject were to simply take truths from others as given, this would constitute ignorance (Sartre, 1995, p. 52). Existentialist truth is incompatible with the idea of blindly taking from others, which would open the door to being in a state of dependence. It means daring to know and thus has an immanent emancipatory thrust.

However, Sartre has not explicitly connected truth to social relations of power and dependence. Rather, his notion of truth still abides by the ideal of an autonomous, self-sufficient subject as described in Being and Nothingness, and it equally remains oblivious to the influence of social forces that might limit the ability of the self to take a reflective stance (Bergoffen, 2009, p. 19). In other words, a general ability to overcome the objectification by the other is located in the subject's consciousness alone. Only in his later work did Sartre explicitly foreground the concrete, situated individual and its embeddedness in social relations (Mrovlje, 2019, pp. 64-66). In the post-war years, Sartre broke with his understanding of radical freedom of the individual consciousness, embracing the idea that the consciousness is conditioned by its social and historical circumstances (Busch, 1989, p. 87).

While Sartre came to recognize how the larger social context may limit the individual's practical freedom and even the will to be free, this role of the societal context had been described earlier and more succinctly by Simone de Beauvoir: With her emphasis on the situatedness of the subject, she offers a perspective that can grasp how oppressive socio-political conditions reduce the ability to attain consciousness of freedom (Kail, 2009, p. 157; Mrovlje, 2019, pp. 70-73; Weiss, 2009, pp. 247-249). According to de Beauvoir (1989, p. 465), structures of oppression are maintained through individuals internalizing these conditions. Consequently, relations of domination 'can permeate subjectivity to the point where consciousness itself becomes no more than a product of the oppressive situation' (Kruks, 2001, p. 36). The stability of structures of oppression thus stems from a process of naturalization - mediated by social relations and institutions that shapes the very beliefs of individuals about themselves and their relation to the world. This affects their ability and inclination to be autonomous subjects taking a reflective stance toward the circumstances in which they find themselves and being able to imagine them differently (Evans, 1998, pp. 135-136; Kruks, 2001, p. 38). In sum, the larger social context shapes and limits not just practical freedom but also individuals' ability and propensity to be self-determining (Mackenzie, 2015).

This perspective is sensitive to how truth relates to the broader socio-political context. It highlights how some circumstances, more than others, will encourage or 
hinder individuals' commitment to truth in the existentialist sense. While the influence of the social and historical context on individuals' subjectivity is more central to Beauvoir's work than to Sartre's, they converge in their understanding which conditions would need to be realized to enable individuals to be free - and to be in the existentialist mode of truth. Beauvoir, like Sartre, emphasizes the importance of mutuality in individuals' tendency to be autonomous subjects. At the heart of her Ethics of Ambiguity lies the idea that 'in order to be genuinely free a person needs to interact with others who are working to develop genuine freedom' (Arp, 2001, p. 47).

Accordingly, a political order that supports the reciprocity in the existentialist notion of truth would have to enable individuals to opt for truth so that they equally enable and encourage others to avoid ignorance. Such conditions would amount to a rather demanding pluralism, one that is marked by solidarity and egalitarian communication. Consequently, drawing on Heter (2008, pp. 123-141), the orientation and engagement that characterizes Sartre's notion of truth can be reconciled only with a democratic order that works toward minimizing forms of dependence and domination and that constantly works toward creating and maintaining spaces of freedom.

In the same vein, it is possible to see the four kinds of ignorance formulated above as complementing different forms of dependence. They are each aligned with a certain way of governing subjects. On the one hand, this can take the form of a disciplining power that requires the submission of one's desires (conformism and fatalism). On the other hand, governing subjects is equally possible through steering by means of activating, mobilizing and channeling desires, thereby directing them toward certain ends (fundamentalism and solipsism). In its subtler forms, described by Foucault (1980) and others (e.g., Bauman, 2000), this entails establishing norms and standards that subjects are driven to fulfill as an expression of their own self-realization. Drawing on Sartre's notion of ignorance, one can discern an element of ambivalence that is common to those different forms of exerting power. While they aim to foster relations of dependence, they also promise to relieve subjects from the burden of having to renegotiate and to adapt their beliefs and desires.

In sum, the existentialist notions of truth and ignorance exhibit a political dimension. They are bound up with the question how the relation between the individual subject and the broader socio-political setting is organized. In a similar vein, as the subsequent section argues, truth and ignorance can also be used to problematize the shape that democratic politics can take. Specifically, they can be employed to shed light on how democratic politics can be organized in different ways and how some of these amount to subversions from within.

Drawing on Sartre for that purpose may seem odd since his political convictions were a strong blend of socialism and libertarianism that led him to criticize all forms of authority and to advocate radically egalitarian social relations (Flynn, 
1979). He was highly critical of liberal democracy and had little respect especially for citizen representation via elections. However, his criticism was targeted more at really existing liberal-democratic regimes - which he called false democracies and not so much at the ideas that they are supposed to embody (McBride, 2005). His thought is thus compatible at least with an emancipatory reading of democratic politics (Hendley, 1991, p. 84; Heter, 2008, p. 111) and thus with liberal democracy broadly understood as a regime that combines a liberal and a democratic pillar.

Indeed, Sartre himself has made redemptive comments about liberal-democratic politics and even hinted at a link between politics and the level of individual existence: In his final interview, he claimed that the distinction between direct and indirect democracy was of subordinate importance and went on to state that 'democracy seems to be not only a form of government, or a way of granting power, but a life, a way of life. One lives democratically, and in my view human beings today should live in that way and in no other' (Sartre and Lévy, 1996, p. 83). The following section carries this thought further and shows how there is also a way of doing democratic politics much like truth is a mode of being.

\section{Liberal democracy and commitment to truth}

Not unlike the individual, a liberal-democratic regime faces an ongoing task of finding out what it wants - it needs to determine which goals and values are realized in a political decision-making that is ultimately tied back to the views and preferences of the demos. And analogous to the relation between the self and the world, the link between citizens' preferences and a polity's guiding political goals and values can be given different forms. How this is done amounts to a specific way of dealing or not dealing with ambiguities and tensions that mark that relationship.

Conceiving the shape of democratic politics along the lines of an existentialist commitment to truth would mean that the political process takes a specific form: It would be imbued with a readiness to see the relation between citizens' views and the political will expressed in the decision-making as always incomplete. The political process must not be guided by the idea that a correspondence between those two sides should and can ever be realized - even though such a correspondence would seem well in line with the general idea of the rule of the demos.

This vision of democratic rule closely mirrors the post-foundationalist view found among difference democrats. There are particularly notable parallels of Sartre's thought to that of Lefort (1986), who has likened democratic politics to an 'uncontrollable adventure' (Lefort, 1986, p. 305), an open-ended process of society constantly constituting itself. For Lefort, a need for continuously questioning power and debating who is to speak in the name of the people arises because society is fundamentally non-identical with itself - its identity is always open to question and 
can never be based on some unifying foundation (Lefort, 1986, pp. 303-304). Following Lefort (1986), modern democratic rule is attuned to this condition because it acknowledges that any expression of the political will of a society is provisional. Democratic government means accepting division and conflict as a constitutive part of politics by institutionalizing and thus perpetuating while also limiting it. This way, it avoids that dominant interests are instituted, or as Lefort (1986, p. 279) puts it: that the place of power is kept empty.

The difference-democratic, agonistic view emphasizes the importance of preventing the eradication of differences and contingencies which mark the political, and thus of possibilities to contest the status quo as well as possible closures or exclusions (Wingenbach, 2011, pp. 51-53). This openness does not mean that conflict is completely boundless, however. To guarantee the open horizon of ongoing contestation, institutional boundaries are needed. This becomes apparent in the Mouffe's (2009) agonistic model. Although it is informed by a strong criticism of an overly liberalist model of democracy, Mouffe also stresses the role of limitations through commonly accepted liberal principles and rules that tame, but also enable, political struggle among actors who can see each other as equals on a level playing field (Mouffe, 2009, p. 102; on this point, see also Vasilev, 2015). Similarly, Tully (2002) has emphasized that agonistic democratic politics need to be regulated by a constitutional framework which limits conflict and establishes an arena for pluralist contestation. This contestation may even include challenging and amending that very framework itself, as long as the same kind of openness and revisability is still guaranteed in the future (Tully, 1999, pp. $168-169,2002$, p. 208). ${ }^{3}$

In sum, liberal democracy conceived along these lines embodies the idea that there will always be an occasion and legitimate ways to contest the status quo. Through guaranteeing ongoing pluralist conflict and revisability of decisions structured by institutional bounds that are subject to re-interpretation themselves it promises to create unity out of diversity without eliminating that diversity. This shape of democratic politics corresponds to the existentialist commitment to truth in that it too emphasizes an openness toward the future and a readiness to undergo change - specifically through the demos renegotiating the goals and values that guide the polity and that are expressed in political decision-making.

For politics as an ordering and reordering of society to take place, the demos must dare to form a political will and let conflict among different views play itself out - i.e., these need to be advocated and contested. This amounts to a rather demanding conception of democratic politics. Existing liberal democracies may in various ways correspond to it as they institutionalize openness and revisability based on regular elections and political competition, a vibrant civil society, and a pluralist public sphere. However, they are pulled in a different direction to the extent that they show tendencies which shut down ongoing contestation. Importantly, such a closure of politics can even be an outgrowth of the political 
process itself - specifically through attempting to realize the rule of the people without the burdensome ongoing reflexive process of political will formation. As the following section argues, Sartre's notion of ignorance can be used as a lens to reflect upon such tendencies as inherent challenges and subversions to liberal democracy.

\section{The threat of ignorance in democratic politics}

Ignorance on the level of the individual existence is guided by the idea that any tensions between the self and the world can be removed, so that the need to engage with the demands from the world is eliminated. Similarly, democratic politics may be marked by tendencies or attempts to organize democratic politics in a way that promises to achieve a lasting congruence between citizens' preferences and the decision-making of the polity. This only seemingly realizes the rule of the people, however, as it threatens to eliminate an open horizon of future instances in which citizens practice their equal freedom to engage in will formation and to possibly revise political decisions. In this sense, liberal democracy too can show signs of ignorance in the existentialist sense.

As will be argued in the following, there are various ways in which such ignorance can manifest itself as subversive tendencies in liberal democracy that aim at eliminating its immanent tensions. These tendencies undermine the kind of reflexive process described in the previous section and mirror the different modes of ignorance formulated further above. In the political realm, such tendencies all have in common that they are visions of democratic politics which foreclose a process of will formation marked by ongoing contestation and revisability of decisions.

There are - again as a primary distinction ${ }^{4}$ - two opposite tendencies concerning how a congruence between citizens' preferences and political decision-making can seemingly be realized. First, one may cling to the idea of an unmediated expression of citizens' preferences in political decisions, such that there is no tension or room left for the negotiation of what the public will should be. Second, this tension can equally be eliminated through the opposite tendency, by leaving decision-making entirely up to others. Citizens then completely rely on political authorities and simply follow the course that these set out. Both these ways of envisioning the relationship between the demos and the political leave no room for negotiating and contesting decisions and the political will expressed in these decisions. As such, they shut down an open and reflexive political process that would guarantee the continued freedom of citizens to take part in political will formation.

This immediate vs. decoupled relationship between citizens and decisions can, in turn, occur in combination with two opposite tendencies on a second dimension: an obsessive commitment to substantive guiding ideas versus a lack of commitment to 
any position or belief. The first of these two variants, a monistic stance, involves adhering to values and beliefs that are defended as infallible. Barber (2003, p. 141) has called this kind of orientation a recourse to an 'independent ground', a higher source of authority that determines on which substantive foundation political decisions must ultimately rest. It thus denies the existence of alternative legitimate positions that may inform political decision-making, thereby removing any occasion for contestation (Barber, 2003; Dworkin, 1990).

The counterpart to this orientation is equally incompatible with a commitment to truth in the sense described above. A relativist stance, which lacks a commitment to any position or belief equally removes the occasion for ongoing contestation and will formation because relativism makes public reasoning and political judgment pointless. It absolves from the task of engaging other views, since each political view and preference is equally valid anyway. Such a relativist stance thus needs to be distinguished from pluralism. Pluralism implies that citizens and political actors firmly advocate a certain position but at the same time respect the views that others hold and show at least some degree of readiness to change their own views (Hirschman, 1989; Ish-Shalom, 2016). In sum, both monism and a relativism remove the occasion for an ongoing process of public opinion and will formation.

Combining (a) the monistic versus relativist orientation with (b) the immediate versus decoupled relationship between citizens and political decision-makers, one arrives at four types. Each of them represents a way in which democratic politics can deviate from a shape that expresses a commitment to truth in the sense described above. Mirroring conformism, elitist politics is marked by a trust in a higher authority of certain ideas or beliefs that justifies leaving political decisionmaking entirely to those governing. Such a higher authority that guides political decision-making could take the form of religious tenets (theocracy), scientific knowledge or expertise (technocracy) or charismatic authority (plebiscitarian rule). In any case, this vision of politics eschews a commitment to truth and instead follows the promise that by simply accepting the decision of some higher authority and a presumed best political course, ambiguity and conflict can be resolved while the will of the demos is realized.

A second vision of democratic politics that parallels ignorance similarly leaves it to politicians to manage political matters for citizens. Yet this form of politics does not resort to some higher authority adhering to a specific world view, but instead shows no commitment to any view or position. Politics is then not about political elites firmly pursuing programmatic ideas. Rather, these formulate programmatic proposals for the purpose of gaining and staying in power while citizens content themselves with the outputs that this process produces. It thus resembles a postdemocratic vision of politics (Crouch, 2004), in which elites form closed-off circles of political and economic interests that sustain their power and manage public affairs while liberal democracy is still formally intact and can count on the tacit citizen support. This kind of political quietism altogether resembles ignorance 
taking the form of fatalism. What makes this kind of politics tempting is that it may appear less burdensome to citizens to be politically passive, disengaged and acquiescent to political decisions, as they rely on political elites to sort out the right political course for the polity.

In contrast, populist politics parallels a fundamentalist or dogmatic existential orientation. When understood according to a common definition as an orientation that wants political decisions to express a presumed unitary and true will of the people vis à vis unrepresentative elites (Mudde, 2004), populism corresponds to ignorance as described above. This assessment may not generally be as clear-cut when looking at concrete populist movements because there may well be different facets to them. While populist forces and resentment may fuel a politics that is marked by dogmatism or identitarianism, they may also exhibit what Canovan (1999) calls a redemptive element as they push against solidified elitist structures and channel resentment against a representation deficit (Cramer 2016). ${ }^{5}$

Yet to the extent that a populist vision of politics aspires an idealized state of congruence between political decisions and the preferences of the demos, i.e., without having to face the burdensome process of translating competing views into political decisions, it corresponds to ignorance. The more this is the case, the more populist politics has an anti-pluralist thrust that denies a need to engage with other views and for a continued political struggle about the goals of the polity (Abts and Rummens, 2007; Urbinati, 2014). Rather, it takes the presumed true popular will as the only legitimate source of authority and aims for realizing this will as directly as possible, i.e., without any tension or gap between governing and governed (Abts and Rummens, 2007; Arditi, 2005; Urbinati, 2014).

Finally, if the desire for immediacy combines with a relativist stance, i.e., no firm commitment to any political view or position, this leads to a sort of nihilist politics. It indulges in the idea that political decisions can immediately realize what citizens want. Drawing on Novak's (1997, p. 6) writings about the dangers of relativism in politics, such a nihilism is a threat to democratic politics as it implies that one is not bound in any way and thus 'free' to give into every desire. In other words, whatever citizens or the majority of citizens opine, feel and demand, those governing are supposed to translate it into decisions as directly as possible. Politicians are merely expected to follow citizens' demands without questioning and negotiating them in any way. Citizens are - akin a customer - always right. Their desires are not to be questioned, absolving them from any commitment to facts or truth.

Table 2 sums up the four tendencies and visions of democratic politics paralleling the existentialist notion of ignorance. As a feature of democratic politics, they concern the overall shape of the political process and can therefore not be reduced to individual actors, e.g., a part of the demos or political authorities. Nonetheless, the degree to which they manifest themselves in politics will depend on the presence of social and political forces that work toward their realization. For instance, certain political actors might advocate and enact a populist or technocratic 
Table 2: Four tendencies in democratic politics that mirror existentialist modes of ignorance.

\begin{tabular}{lll}
\hline & $\begin{array}{l}\text { Citizens acquiesce in political } \\
\text { decisions taken for them }\end{array}$ & $\begin{array}{l}\text { Citizens' preferences are directly } \\
\text { mirrored in political decisions }\end{array}$ \\
\hline $\begin{array}{l}\text { Only one legitimate position } \\
\begin{array}{c}\text { No position more legitimate } \\
\text { than any other position }\end{array}\end{array}$ & $\begin{array}{l}\text { Democratic elitism } \\
\text { Political quietism }\end{array}$ & $\begin{array}{l}\text { Populist politics } \\
\text { Nihilist politics }\end{array}$ \\
\hline
\end{tabular}

notion of democratic politics, which resonates positively with a considerable part of the demos. The more the political process is marked by attempts to orient it toward any of the four visions in Table 2, the more this undermines conditions which can guarantee the continued equal freedom of all citizens to take part in will formation. In this sense, the four types in Table 2 represent threats to liberal democracy coming from within.

\section{Conclusion}

Sartre (1995) offers an existentialist notion of truth that differs from a common, propositional understanding. It refers to a mode of being that involves the readiness or courage to reveal the world - its contingency and ambiguity - and to deal with the resistances and tensions that this entails. Only in this mode, according to Sartre (1995), is it possible to consciously engage with and to accept the world, and in that sense to take responsibility for it and be free. Ignorance as the counterpart to truth means trying to evade these tensions and indulging in the idea that a state without such tensions can be achieved and perpetuated.

Taking Sartre's concept of ignorance further, the present article has distinguished between different and inter-related forms in which ignorance can manifest itself. They all represent ways of eliminating resistances that may stem from the world. These different forms of ignorance, like truth, furthermore have direct political implications because they entail certain relations to others and to the larger sociopolitical context. Specifically, they all complement and sustain different kinds of power relations.

Beyond such a general political dimension that can be made out in existentialist truth and ignorance, these can be used more specifically to grasp and critically examine different shapes that democratic politics may take. They offer a way of thinking about how trying to eliminate inherent tensions and ambiguities in the human condition - instead of acknowledging and confronting them - only seemingly leads to freedom. This makes them directly relevant for democratic theory since liberal democracy is characterized by irresolvable tensions. The existentialist notion of ignorance can illuminate how attempts to overcome tensions 
at the heart of democratic politics undermine the promise of creating unity out of diversity without however eliminating this diversity. This makes the existentialist concepts of truth and ignorance altogether valuable for thinking about immanent challenges that liberal democracy faces.

As has been shown above, Sartre's concept of ignorance allows for tracing the contours of different visions of democratic politics. They represent different ways of organizing the relationship between citizens' views and political decisionmaking, and they correspond to different forms of ignorance as fundamental existential orientations on the level of the individual existence. An elitist understanding of democratic politics - corresponding to conformism on the level of the individual existence - is marked by a submission under the leadership of some higher, e.g., technocratic, authority that guides political decision-making. A populist vision of politics - corresponding to dogmatism - indulges in the idea that some (imagined) true popular will is the only valid source of authority and can immediately be expressed in political decisions. In the quietist vision of democratic politics - corresponding to fatalism - citizens simply leave it to political elites to pragmatically sort out political matters in the interest of the citizens without a firm commitment to any position. Finally, a nihilist understanding of politics corresponding to solipsism - is akin to a consumer mentality, adhering to the idea that political decisions can and should immediately realize whatever citizens desire. Politicians and politics are simply there to comply with citizens' wants.

These four ways of organizing democratic politics are all in line with the democratic idea that political decisions should be taken in the interest of the citizens. Yet they also have in common that they aim to eradicate the tensions between citizens' views, on the one hand, and the guiding goals and values expressed in political decision-making, on the other hand. They express the tempting idea that a correspondence between those two sides can be realized without a continuous renegotiation of that relationship. In other words, they aim to escape the arduous process of figuring out what the political will should be. The more such a tendency expresses itself in the political process, however, the less room there is for an ongoing process of will formation that is marked by pluralist contestation and revisability.

To guarantee adaptiveness through revisability and an open horizon in democratic politics, liberal democracy instead requires a commitment to truth in the existentialist sense - a commitment that needs to be embodied in its institutions and in the mindset of the members of the polity. Such a commitment to truth does precisely not mean to start from some truth as a solid ground, nor to aspire to reach it. At the same time, it does not succumb to mere relativism either. This nonfoundationalism in Sartre's thought is not only a fruitful basis for an account of political judgment that recognizes ambiguity and the contingency of the human condition (Mrovlje, 2019), but it can also inform political thought about the working of liberal democracy: why it is perpetually precarious vis à vis various recurring temptations to evade democracy's burdensome political freedom. 


\section{Acknowledgments}

Open Access funding provided by Projekt DEAL. I thank the anonymous reviewers for their immensely thoughtful and constructive comments. Thanks also go the editors of Contemporary Political Theory for their helpful comments and suggestions, and to Stefanie Thurm for helping with preparing an earlier version of the manuscript.

Open Access This article is licensed under a Creative Commons Attribution 4.0 International License, which permits use, sharing, adaptation, distribution and reproduction in any medium or format, as long as you give appropriate credit to the original author(s) and the source, provide a link to the Creative Commons licence, and indicate if changes were made. The images or other third party material in this article are included in the article's Creative Commons licence, unless indicated otherwise in a credit line to the material. If material is not included in the article's Creative Commons licence and your intended use is not permitted by statutory regulation or exceeds the permitted use, you will need to obtain permission directly from the copyright holder. To view a copy of this licence, visit http:// creativecommons.org/licenses/by/4.0/.

\section{About the Author}

Pascal D. König is a researcher at the Department of Social Sciences of the Technische Universität-Kaiserslautern in Germany. His research mainly deals with political communication, party competition, and the effects of digital technologies on democratic government. Recent work has appeared in Philosophy \& Technology, Policy \& Politics, and Government Information Quarterly.

\section{Notes}

1 It can also be read from sociological diagnoses of late modernity, which is marked by tendencies toward identity-based conformity and the narcissism of consumer society to constantly reinvent oneself and indulge in wants and desires (e.g., Bauman, 2000).

2 On this see also the 'wantons' described by Frankfurt (2013, p. 257).

3 A similar understanding of democratic politics that keeps pluralist conflict and contestation alive is also shared by some proceduralist accounts of democratic politics (see, e.g., Knight and Johnson, 2011; Urbinati, 2014).

4 For a broader discussion of the distinctions made here from the point of view of comparative politics, see König and Siewert (2020).

5 I thank an anonymous reviewer for pointing to the often more complex nature of populist movements. 


\section{References}

Abts, K., and Rummens, S. (2007) Populism versus democracy. Political Studies 55(2): 405-424.

Arditi, B. (2005) Populism as an internal periphery of democratic politics. In: F. Panizza (ed.) Populism and the Mirror of Democracy. London, New York: Verso.

Arp, K. (2001) The Bonds of Freedom: Simone de Beauvoir's Existentialist Ethics. Chicago: Open Court.

Barber, B. (2003) Strong Democracy: Participatory Politics for a New Age. Berkeley: University of California Press.

Bauman, Z. (2000) Liquid Modernity. Cambridge: Polity Press; Blackwell.

Bennett, W. L., and Livingston, S. (2018) The disinformation order: Disruptive communication and the decline of democratic institutions. European Journal of Communication 33(2): 122-139.

Bergoffen, D. (2009) Getting the Beauvoir we deserve. In: C. Daigle and J. Golomb (eds.) Beauvoir and Sartre: The riddle of Influence. Bloomington: Indiana University Press.

Busch, T. W. (1989) The Power of Consciousness and the Force of Circumstance in Sartre's Philosophy. Bloomington: Indiana University Press.

Canovan, M. (1999) Trust the people! populism and the two faces of democracy. Political Studies 47(1): $2-16$.

Cox, G. (2009) Sartre and Fiction. London, New York: Continuum.

Cramer, K. J. (2016) The Politics of Resentment: Rural Consciousness in Wisconsin and the Rise of Scott Walker. Chicago, London: University of Chicago Press.

Crouch, C. (2004) Post-democracy. Malden, MA: Polity.

de Beauvoir, S. (1989) The Second Sex. New York: Vintage.

Dworkin, R. (1990) Equality, democracy, and constitution: We the people in court. Alberta Law Review 28(2): 324-346.

Evans, R. (ed.). (1998) Simone de Beauvoir's The second sex: New interdisciplinary essays. Manchester; New York: Manchester University Press.

Flynn, T. R. (1979) The political thought of Jean-Paul Sartre: Three Essays: I. L'Imagination Au Pouvoir: The evolution of Sartre's political and social thought. Political Theory 7(2): 157-182.

Foucault, M. (1980) Power/Knowledge: Selected Interviews and Other Writings, 1972-1977. New York: Pantheon Books.

Frankfurt, H. G. (2013) Freedom of the will and the concept of a person. In: P. Russell and O. Deery (eds.) The Philosophy of Free Will: Essential Readings From the Contemporary Debates. New York: Oxford University Press.

Fritsche, I., Jonas, E., and Kessler, T. (2011) Collective reactions to threat: Implications for intergroup conflict and for solving societal crises. Social Issues and Policy Review 5(1): 101-136.

Fromm, E. (1994) Escape from Freedom. New York: H. Holt.

Hayden, P. (2013) Albert Camus and rebellious cosmopolitanism in a divided Worlda. Journal of International Political Theory 9(2): 194-219.

Hendley, S. (1991) Reason and Relativism: A Sartrean Investigation. Albany: State University of New York Press.

Heter, T. S. (2008) Sartre's Ethics of Engagement: Authenticity and Civic Virtue. London: Continuum.

Hinchman, L. P., and Hinchman, S. K. (1991) Existentialism Politicized: Arendt's Debt to Jaspers. The Review of Politics 53(3): 435-468.

Hirschman, A. O. (1989) Having opinions-one of the elements of well-being? The American Economic Review 79(2): 75-79.

Ish-Shalom, P. (2016) Conceptualizing democratization and democratizing conceptualization: a virtuous circle. In: C. Hobson and M. Kurki (eds.), Conceptual Politics of Democracy Promotion. London: Routledge. 
Kail, M. (2009) Beauvoir, Sartre, and the problem of alterity. In: C. Daigle and J. Golomb (eds.), Beauvoir and Sartre: the Riddle of Influence. Bloomington: Indiana University Press.

Knight, J., and Johnson, J. (2011) The Priority of Democracy: Political Consequences of Pragmatism. Princeton: Princeton University Press.

König, P. D., and Siewert, M. B. (2020) Off balance: Systematizing deformations of liberal democracy. International Political Science Review (online first).

Kruks, S. (2001) Retrieving Experience: Subjectivity and Recognition in Feminist Politics. Ithaca: Cornell University Press.

Kruks, S. (2012) Simone de Beauvoir and the Politics of Ambiguity. New York: Oxford University Press. Landemore, H. (2013) Democratic Reason: Politics, Collective Intelligence, and the Rule of the Many. Princeton: Princeton University Press.

Langford, I. H. (2002) An existential approach to risk perception. Risk Analysis 22(1): 101-120.

Lefort, C. (1986) The Political Forms of Modern Society: Bureaucracy, Democracy, Totalitarianism. Cambridge, MA: MIT Press.

Lewandowsky, S., Ecker, U. K. H., and Cook, J. (2017) Beyond misinformation: Understanding and coping with the 'Post-Truth' era. Journal of Applied Research in Memory and Cognition 6(4): 353-369.

Lippmann, W. (1922) Public Opinion. New York: Harcourt, Brace \& Co.

Mackenzie, C. (2015) Responding to the agency dilemma: autonomy, adaptive preferences, and internalized oppression. In: M. Oshana (ed.) Personal Autonomy and Social Oppression: Philosophical Perspectives. New York: Routledge, Taylor \& Francis Group.

Marso, L. J. (2017) Politics with Beauvoir: Freedom in the Encounter. Durham: Duke University Press.

McBride, W. L. (2005) Sartre at the Twilight of liberal democracy as we have known it. Sartre Studies International 11(1-2): 311-318.

Mirowsky, J., and Ross, C. E. (1990) Control or defense? Depression and the sense of control over good and bad outcomes. Journal of Health and Social Behavior 31(1): 71-86.

Mouffe, C. (2009) The Democratic Paradox. London: Verso.

Mrovlje, M. (2019) Rethinking Political Judgement: Arendt and Existentialism. Edinburgh: Edinburgh University Press.

Mudde, C. (2004) The populist Zeitgeist. Government and Opposition 39: 542-563.

Nichols, T. (2017) The Death of Expertise: The Campaign Against Established Knowledge and Why it Matters. Oxford, New York: Oxford University Press.

Novak, M. (1997) Truth and liberty: The present crisis in our culture. The Review of Politics 59(1): 5-24.

Rae, G. (2014) Realizing Freedom: Hegel, Sartre and the Alienation of Human Being. Basingstoke: Palgrave Macmillan.

Sartre, J.-P. (1995) Truth and Existence. Chicago: Chicago University Press.

Sartre, J.-P. (2012) Being and Nothingness: An Essay on Phenomenological Ontology (23rd print.). New York: Washington Square Press.

Sartre, J.-P., and Lévy, B. (1996) Hope Now: The 1980 Interviews. Chicago: University of Chicago Press.

Schumpeter, J. A. (1975) Capitalism, Socialism, and Democracy. New York: Harper Perennial.

Somin, I. (2013) Democracy and Political Ignorance: Why Smaller Government is Smarter. Stanford: Stanford University Press.

Strenger, C. (2005) The Designed Self: Psychoanalysis and Contemporary Identities. Hillsdale, NJ: Analytic Press.

Suiter, J. (2016) Post-truth politics. Political Insight 7(3): 25-27.

Taylor, C. (1989) Sources of the Self: The Making of the Modern Identity. Cambridge, MA: Harvard University Press.

Tully, J. (1999) The agonic freedom of citizens. Economy and Society 28(2): 161-182. 
Tully, J. (2002) The unfreedom of the moderns in comparison to their ideals of constitutional democracy. The Modern Law Review 65(2): 204-228.

Urbinati, N. (2014) Democracy Disfigured: Opinion, Truth, and the People. Cambridge, MA: Harvard University Press.

Vasilev, G. (2015) On Mouffe's agonism: Why it is not a refutation of consensus. Democratic Theory 2(1): 4-21.

Wallace, D. F. (1997) The Broom of the System. London: Abacus.

Webber, J. (2007) The Existentialism of Jean-Paul Sartre. London: Routledge.

Weber, M. (1978) Economy and Society: An Outline of Interpretive Sociology (Vol. 2). Berkeley: Univ. of California Press.

Weiss, G. (2009) Freedom f/or the other. In: C. Daigle and J. Golomb (eds.) Beauvoir and Sartre: The Riddle of Influence. Bloomington: Indiana University Press.

Wingenbach, E. C. (2011) Institutionalizing Agonistic Democracy: Post-Foundationalism and PoliticalLiberalism. Milton Park: Routledge.

Wrathall, M. A. (2011) Heidegger and Unconcealment: Truth, Language, and History. Cambridge: Cambridge Univ. Press.

Publisher's Note Springer Nature remains neutral with regard to jurisdictional claims in published maps and institutional affiliations. 